\title{
Quantification of glucosylceramide in plasma of Gaucher disease patients
}

\author{
Maria Viviane Gomes Muller ${ }^{1,2}$, André Petry ${ }^{1}$, Luciene Pinheiro Vianna ${ }^{1}$, Ana Carolina Breier ${ }^{1}$, \\ Kristiane Michelin-Tirelli ${ }^{3}$, Ricardo Flores Pires ${ }^{4}$, Vera Maria Treis Trindade ${ }^{2}$, \\ Janice Carneiro Coelho ${ }^{2, *}$
}

\begin{abstract}
${ }^{1}$ Biochemistry Department, Health Basic Sciences Institute, Federal University of Rio Grande do Sul, Porto Alegre, ${ }^{2}$ Pharmacy and Biology Department, University of Santa Cruz do Sul, Santa Cruz do Sul, ${ }^{3}$ Medical Genetics Service, Hospital de Clínicas de Porto Alegre, ${ }^{4}$ Medicine Course, Luteran University of Brazil
\end{abstract}

\begin{abstract}
Gaucher disease is a sphingolipidosis that leads to an accumulation of glucosylceramide. The objective of this study was to develop a methodology, based on the extraction, purification and quantification of glucosylceramide from blood plasma, for use in clinical research laboratories. Comparison of the glucosylceramide content in plasma from Gaucher disease patients, submitted to enzyme replacement therapy or otherwise, against that from normal individuals was also carried out. The glucosylceramide, separated from other glycosphingolipids by high performance thin layer chromatography (HPTLC) was chemically developed $\left(\mathrm{CuSO}_{4} / \mathrm{H}_{3} \mathrm{PO}_{4}\right)$ and the respective band confirmed by immunostaining (human anti-glucosylceramide antibody / peroxidase-conjugated secondary antibody). Chromatogram quantification by densitometry demonstrated that the glucosylceramide content in Gaucher disease patients was seventeen times higher than that in normal individuals, and seven times higher than that in patients on enzyme replacement therapy. The results obtained indicate that the methodology established can be used in complementary diagnosis and for treatment monitoring of Gaucher disease patients.
\end{abstract}

Uniterms: Glucosylceramide. Blood plasma analysis. Gaucher disease.

A doença de Gaucher é uma esfingolipidose caracterizada pelo acúmulo de glicosilceramida. O objetivo deste estudo foi desenvolver metodologia baseada na extração, purificação e quantificação da glicosilceramida plasmática a qual possa ser usada em laboratórios de pesquisa clínica. Após o desenvolvimento desta metodologia, foi proposto, também, comparar o conteúdo de glicosilceramida presente no plasma de pacientes com doença de Gaucher, submetidos ou não a tratamento, com aquele de indivíduos normais. A glicosilceramida, separada de outros glicoesfingolipídios por cromatografia de camada delgada de alto desempenho (HPTLC), foi revelada quimicamente $\left(\mathrm{CuSO}_{4} / \mathrm{H}_{3} \mathrm{PO}_{4}\right)$ e a respectiva banda foi confirmada por imunorrevelação (anticorpo anti-glicosilceramida humana/anticorpo secundário conjudado à peroxidase). A quantificação do cromatograma por densitometria demonstrou que o conteúdo de glicosilceramida nos pacientes com doença de Gaucher era 17 vezes maior que aquele de indivíduos normais e 7 vezes maior que aquele dos pacientes com doença de Gaucher submetidos a tratamento com terapia de reposição enzimática. Os resultados obtidos demonstram que a metodologia estabelecida pode ser usada como diagnóstico complementar e como monitoração do tratamento de pacientes com doença de Gaucher.

Unitermos: Glicosilceramida. Análise plasmática. Doença de Gaucher.

\section{INTRODUCTION}

Gaucher Disease (GD) is a sphingolipidosis caused

\footnotetext{
*Correspondence: J. C. Coelho. Departamento de Bioquímica - ICBS, Universidade Federal do Rio Grande do Sul. Rua Ramiro Barcelos, 2600 - anexo - 90035-003 - Porto Alegre - RS, Brasil. E-mail: janice.coelho@ufrgs.br
}

by a disorder in the metabolism of glycosphingolipids due to a recessive autosomal mutation in the gene of the acid beta-glucosidase ( $\beta$-glu) enzyme. This defect results in the progressive storage of glucosylceramide (GluCer) in the cells of the mononuclear phagocyte system, which are then called Gaucher cells (Beutler, Grabowski, 2001; 
Fost et al., 2003; Futerman et al., 2004; Moyses, 2003). Three different phenotypes are recognized based on the presence (types 2 and 3) or absence (type 1) of neurological involvement. Gaucher Disease Type 1, defined as non-neuropathic, is the most common and occurs in about 99\% of diagnosed cases (Aerts et al., 2003; JakóbkiewiczBanecka et al., 2007).

Treatment of GD is based on enzyme replacement therapy (ERT) and, more recently, on substrate reduction therapy (SRT) (Aerts et al., 2003; Brady, 2003; Jakóbkiewicz-Banecka et al., 2007). In ERT the recombinant enzyme imiglucerase replaces the defective enzyme and splits the accumulated glucocerebroside, while in SRT a small molecule, miglustat ( $N$-butyldeoxynojirimycin), inhibits the synthesis of substrates accumulated in GD. This guarantees that the residual activity of the mutant enzyme is sufficient to avoid the formation of pathological storage (Germain, 2004; Hollak et al., 1994; Zimran, Elstein, 2003).

The methods used to confirm the diagnosis of GD are (i) determination of $\beta$-glu activity and (ii) molecular characterization (Beutler, Grabowski, 2001; Fost et al., 2003; Guo et al., 1995; Wajner et al., 2007). Although chitotriosidase (CT) is often used as a biomarker in GD, mainly in treatment monitoring, Moyses (2003) and Aerts et al (2003) stated that elevated enzyme activity is not a condition specific to this pathology. It has been demonstrated that a mutation in the CT gene, consisting of a duplication of 24 base pairs in exon 10, causes a deficiency of CT activity in $6 \%$ of the world's population, which invalidates its use as a specific biomarker (Guo et al., 1995; Hollak et al., 1994). In view of this scenario, it is clear that other biomarkers are necessary.

The quantification of glucosylceramide (GluCer) accumulated in GD is a strong candidate as a biomarker for this pathology (Gornati et al., 1998). However, it is not widely used in practical biochemistry because of the difficulties in the quantification methods. According to Groener et al. (2007), the quantification of GluCer by mass spectrometry is highly laborious and costly, and requires sophisticated equipment and specialized operators. These same authors suggest that GluCer could be quantified by HPLC (High performance liquid chromatography), but this technique also requires sophisticated and costly equipment, which is not always available to clinical analyses laboratories.

In this study, we proposed a methodology for GluCer evaluation that can be carried out in clinical laboratories. It is based on the extraction and purification of this glycosphingolipid from blood plasma, with the subsequent quantification by densitometry of the GluCer band separated by HPTLC. We also compared the GluCer content from plasma of GD patients submitted to ERT or otherwise, with that of normal individuals.

\section{MATERIAL AND METHODS}

\section{Samples}

Peripheral venal blood ( $5 \mathrm{~mL}$ ) was collected from 15 individuals using heparinized syringes. Blood plasma was separated by centrifugation at $600 \mathrm{x} g$ for 10 minutes and stored at $-40^{\circ} \mathrm{C}$ until required. The samples of normal individuals $(\mathrm{n}=5)$ came from a blood bank supplied by voluntary donors, while the samples of individuals with GD $(n=10)$ were collected from patients diagnosed in the Genetic Medical Service of the Hospital de Clinicas de Porto Alegre (HCPA), Rio Grande do Sul, Brazil according to $\beta$-glucosidase activity. $\beta$-glucosidase activity in all GD patients was between 0 and $5 \mathrm{nmol} / \mathrm{h} / \mathrm{mg}$ of protein (normal values are between 10 and $45 \mathrm{nmol} / \mathrm{h} / \mathrm{mg}$ of protein). The study was conducted in conformity with the Helsinki Declaration of the World Medical Association and was approved by the Committee of Ethics of HCPA. All the participating individuals signed an informed consent.

\section{Methods}

Figure 1 shows a flow chart of the methodology used in this study. This methodology will be described in detail below.

\section{Total lipid extraction}

Total lipids were extracted according to Doering et al (1999) with the modifications required to use plasma samples. Plasma $(600 \mu \mathrm{L})$ of each individual was sequentially treated with chloroform: methanol (C:M) mixtures in the proportions of $1: 2(1800 \mu \mathrm{L}), 1: 1(1200 \mu \mathrm{L})$ and 2:1 $(1800 \mu \mathrm{L})$, at $37^{\circ} \mathrm{C}$, for 2 hours under constant shaking. These three extracts were mixed and solvent mixtures evaporated. The dry residue obtained was denominated total lipid extract.

\section{Purification and isolation of GluCer}

Silicic acid column (Sigma-Aldrich, Saint Louis, MO, USA): the total lipid extract residue was suspended in $1 \mathrm{~mL}$ of chloroform (C)/methanol (M) (98:2) mixture and submitted to a silicic acid (500 mg) column according to Ullman and McCluer (1977). The C/M (98:2) eluate (apolar fraction) $(2000 \mu \mathrm{L})$ was discarded. The acetone 


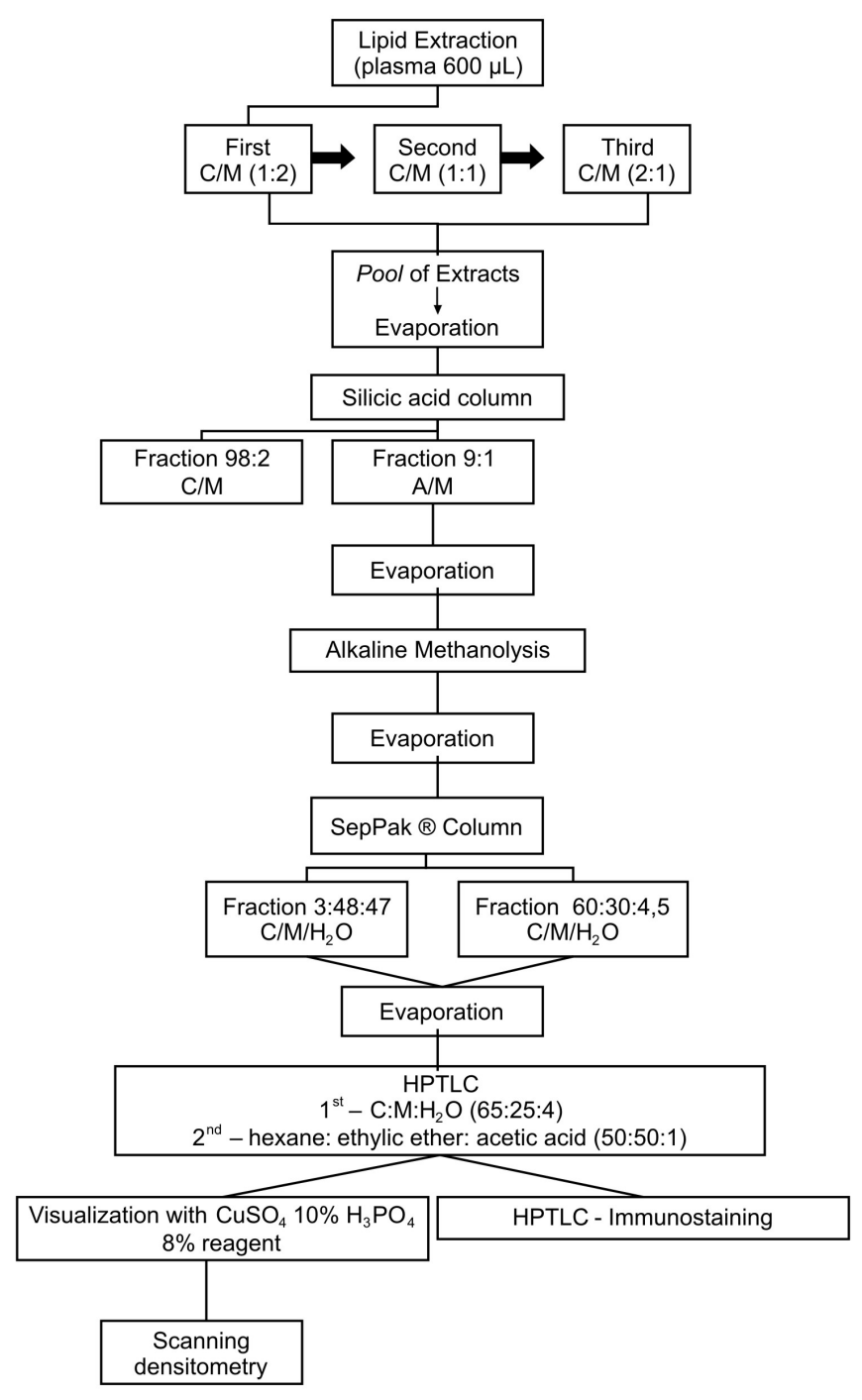

FIGURE 1 - Flow-chart of methodology used. Details are described in the text.

(A)/methanol (M) (9:1) eluate (polar fraction) $(2000 \mu \mathrm{L})$ was evaporated and the dry residue was submitted to gentle alkaline methanolysis.

Alkaline methanolysis: The dry residue of the $\mathrm{A} / \mathrm{M}$ (9:1) fraction obtained from the silicic acid column was suspended in $1 \mathrm{~mL}$ of a $0.6 \mathrm{~N} \mathrm{NaOH}$ methanolic solution and incubated for 90 minutes at $37^{\circ} \mathrm{C}$, as described by Ullman and Mc Cluer (1977). This procedure hydrolyzes phosphoglycerolipids, but not glycosphingolipids.

Sep-pack ${ }^{\circledR}$ with $\mathbf{C} 18$ cartridges column (Waters, Milford, MA, USA): The material obtained by alkaline methanolysis was evaporated under nitrogen gas flow. The residue was suspended in C:M (1:1) $(1000 \mu \mathrm{L})$ and submitted to the Sep-Pack ${ }^{\circledR}$ column (65 mg) to eliminate salts and low molecular mass compounds and purify glycosphingolipids (Williams and McCluer, 1980). Two eluates of $\mathrm{C} / \mathrm{M} /$ water $(3: 48: 47)(3000 \mu \mathrm{L})$ and $(60: 30: 4.5)$
$(1600 \mu \mathrm{L})$ were collected from the Sep-Pack ${ }^{\circledR}$ column and stored as a pool. This purified material was evaporated under nitrogen gas flow at $37^{\circ} \mathrm{C}$ and the residue analyzed by chromatography.

\section{Analysis by High Performance Thin Layer Chromatography (HPTLC)}

The purified glycosphingolipid fraction was analyzed by HPTLC (Silica Gel 60 A, 20 x $10 \mathrm{~cm}$ plates, Merck, Darmstadt, Germany). In order to allow application, each residue was suspended in $50 \mu \mathrm{L}$ of $\mathrm{C} / \mathrm{M}(1: 1)$. Two solvent systems were used, according to Tani-ichi et al (2005). The first consisted of $\mathrm{C} / \mathrm{M} /$ water $(65: 25: 4)$, and the second of hexane/ethylic ether/acetic acid (50:50:1). The chromatogram was visualized by spraying with $10 \% \mathrm{CuSO}_{4}$ and $8 \%$ $\mathrm{H}_{3} \mathrm{PO}_{4}$ in water, and heating at $150{ }^{\circ} \mathrm{C}$ (Doering et al., 1999). GluCer (Sigma-Aldrich, Saint Louis, MO, USA) was used as the standard. GluCer was quantified by densitometry scanning of the chromatogram with a CS 930 Shimadzu $\mathrm{UV} /$ vis densitometer. These results were compared with a chromatogram obtained from known quantities of GluCer, according to Gonarti et al. (2002). We measured recoveries of GluCer by standard addition of this lipid to normal plasma. The amount of GluCer was a linear function of the amounts added, and recovery was about $11.2 \%$.

The linearity of GluCer quantification is shown in Figure $2(r=0.98)$. These data were obtained by densitometric scanning of standard GluCer content after chromatographic performance. The intra-assay $\mathrm{CV}(\mathrm{n}=6)$ measured in control and GD plasma was $<5.3 \%$ for GluCer. The inter-assay CV ( $\mathrm{n}=6)$ was $<9 \%$.

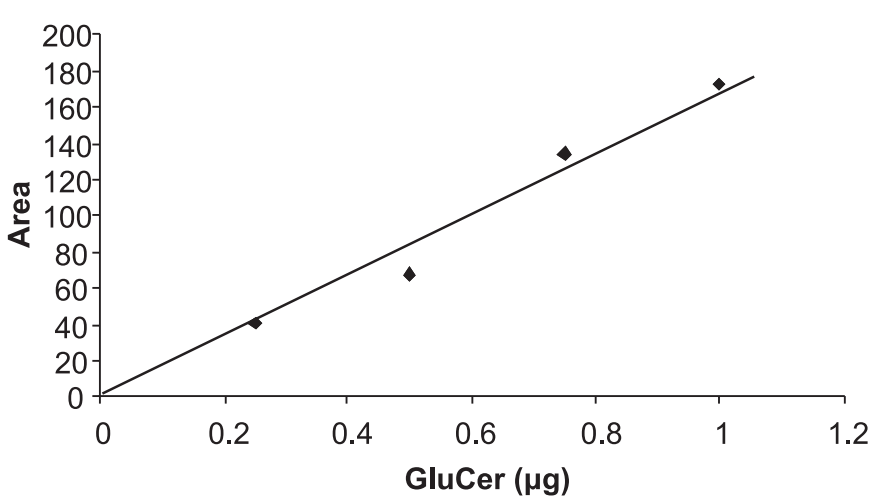

FIGURE 2 - Linearity of GluCer measurement in plasma. Area determined by densitometric scanning of GluCer band from chromatogram.

\section{Protein quantification}

The proteins were determined from each plas- 
ma sample by the Biuret method according to the manufacturer's instructions (Biuret Reagent - total proteins, Labtest, Lagoa Santa, MG, Brazil) and described by Gornal et al. (1949).

\section{HPTLC-Immunostaining}

The confirmation of the GluCer band identity was carried out by immunostaining using the procedure described by Brade et al. (2000) with modifications for the blocking buffer (Haycock 2003). The immunostaining was started by chromatogram incubation in a blocking buffer (50mM Tris- $\mathrm{HCl} \mathrm{pH} 7.4 ; 200 \mathrm{mM} \mathrm{NaCl} ; 0.1 \%$ Polyvinylpyrrolidone, Sigma-Aldrich, Saint Louis, MO, USA) for two hours at $24{ }^{\circ} \mathrm{C}$ with gentle shaking. Subsequently, the chromatogram was incubated with the primary antibody (human anti-glucosylceramide rabbit antibody) (Glyco-Tech Produktions und Handelsgesellschaft mbH, Kuelkels, Germany) diluted to 1:500 in a washing buffer (50 mM Tris-HCl pH 7.4; $200 \mathrm{mM} \mathrm{NaCl}$ ) for four hours at $24{ }^{\circ} \mathrm{C}$ with gentle shaking.

After five washes with the washing buffer, the chromatogram was incubated with peroxidase-conjugated goat anti-rabbit immunoglobulin (IgG) (heavy and light chain specific, Dianova, Sigma- Aldrich, Saint Louis, MO, USA), diluted in a washing buffer (1:1000) for two hours, at $24{ }^{\circ} \mathrm{C}$ with gentle shaking. Next, four washes as described above were performed and a fifth wash was conducted with the substrate buffer ( $0.1 \mathrm{M}$ sodium citrate, $\mathrm{pH} 4.5)$.

Bound antibody was then detected by incubation of the chromatogram for 30 minutes at $24^{\circ} \mathrm{C}$ in a freshly prepared substrate solution $(10 \mathrm{~mL})$ composed of $8.33 \mathrm{~mL}$ of substrate buffer; $1.6 \mathrm{~mL}$ 4-chloro-1-naphthol (3 mg/mL in $\mathrm{MeOH})$ and hydrogen peroxide $(3.3 \mu \mathrm{L}$ in a $30 \%$ solution) (Haycock, 2003). The immunoassay results are shown in Figure 3B, lines 1b, 2b and 3b.

\section{Statistical analysis}

To determine significant differences between groups $(p<0.05)$ the one-way ANOVA was applied followed by the Tukey test, when necessary. The tests were conducted using the SPSS-PC version 12 software package.

\section{RESULTS}

The methodology used in this study allowed extraction (C/M), purification (Silicic Acid Column, Methanolysis and Sep-Pack column), separation and detection (HPTLC with chemical developing) of GluCer in the plasma of GD patients receiving ERT or otherwise, as well as GluCer of normal individuals (Figure 3A, band 1). The presence of GluCer (band 1) in the chromatogram was confirmed by immunostaining with human anti-glucosylceramide (primary antibody), followed by goat anti-rabbit immunoglobulin (secondary antibody) conjugated with peroxidase (Figure $3 \mathrm{~B}$, lines $1 \mathrm{~b}$ and $2 \mathrm{~b}$ ). This band was detected only in the subjects from lines 4, 5 and 7 (Figure 3A), GD patients without treatment.

Figure 3A, lines 4, 5, 6, 7, 8, 9 and 10, shows another band (band 2) with migration velocity slightly higher than GluCer standard (band 1), with similar content in all samples. Band 2 was also immunostained (Figure 3B). This band could be another glucocerebroside with a different sphingoid chain that is present in all individuals.

Table I shows the GluCer concentrations (GluCer content ratio obtained by densitometric analysis and plasma volume or protein content). The data confirmed previous findings, that is, the concentration of GluCer expressed in different units is significantly higher $(p<0.001)$ in GD patients not receiving treatment compared to normal individuals or to GD patients being treated with ERT. There was no significant difference between the plasmatic

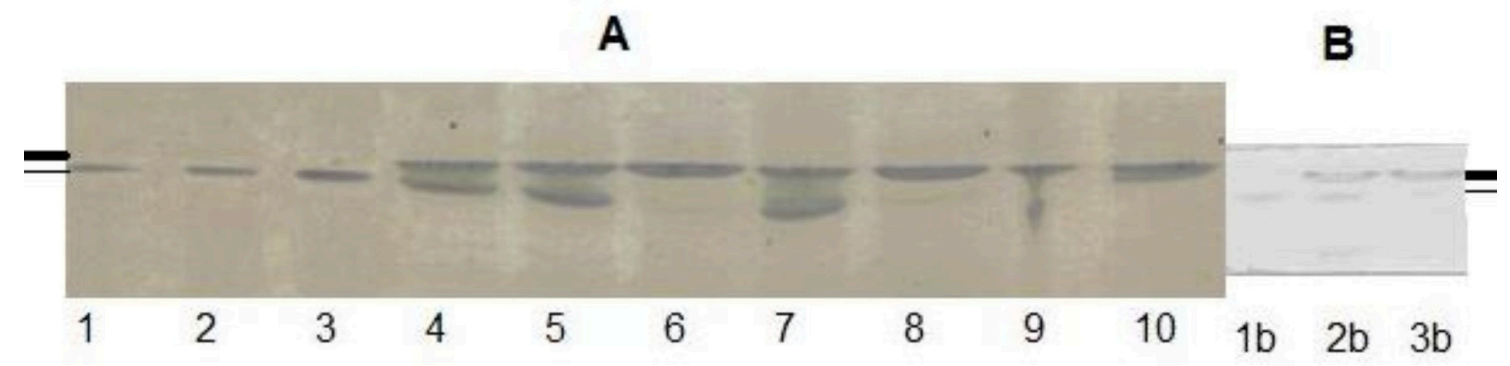

FIGURE 3 - Analysis by HPTLC of purified lipid extracts of plasmas obtained from GD patients on ERT or otherwise, and normal individuals. Band $1(-)$, band 2 (-). A. Processing in $\mathrm{CuSO}_{4} 10 \% / \mathrm{H}_{3} \mathrm{PO}_{4} 8 \%$ (lines 1,2 and 3 correspond to the GluCer standard $0.25 \mu \mathrm{g}, 0.5 \mu \mathrm{g}$ and $1.5 \mu \mathrm{g}$, respectively). Lines 4,5 and 7 refer to GD patients without treatment while lines 6 and 8 represent GD patients on ERT. Lines 9 and 10 represent samples from normal individuals. B. Immunoprocessing (1b standard GluCer $0.5 \mu \mathrm{g}$; $\mathbf{2 b}$ GD patient without treatment and $\mathbf{3 b}$ normal individual). 
TABLE I - Concentration of GluCer in plasma of GD patients with and without ERT, compared to normal individuals

\begin{tabular}{lccc}
\hline Groups & $\begin{array}{c}\text { GluCer } \\
(\mu \mathrm{g} / 600 \mu \mathrm{L} \text { plasma })\end{array}$ & $\begin{array}{c}\text { GluCer } \\
(\mu \mathrm{mol} / \mathrm{L} \text { plasma })\end{array}$ & $\begin{array}{c}\text { GluCer } \\
(\mathrm{ng} / \mathrm{mg} \text { protein })\end{array}$ \\
\hline Normal $(\mathrm{n}=5)$ & $0.03 \pm 0.03^{*}$ & $0.07 \pm 0.07^{*}$ & $0.67 \pm 0.78^{*}$ \\
GD without treatment $(\mathrm{n}=5)$ & $0.57 \pm 0.24$ & $1.59 \pm 0.27$ & $13.7 \pm 1.25$ \\
GD with ERT $(\mathrm{n}=5)$ & $0.05 \pm 0.02^{*}$ & $0.11 \pm 0.04^{*}$ & $1.23 \pm 0.68^{*}$ \\
\hline
\end{tabular}

Results expressed as mean \pm SD $(n=5)$.

* Statistically different from GD without treatment group, $p<0.001$ by ANOVA followed by Tukey's test.

GluCer levels of normal individuals compared to those of GD patients on treatment.

\section{DISCUSSION}

Gaucher Disease is the most common lysosomal storage disease. It is an autosomal recessive disorder caused by a deficiency in $\beta$-glu enzyme that leads to an accumulation of GluCer in the lysosomes, mainly in cells of the reticuloendothelial system. The present study described a methodology to extract, purify and quantify GluCer in plasma of GD patients, and compared these results with those of normal individuals. In addition, the quantity of GluCer of patients with GD receiving treatment was compared with that of patients who were not in use of any form of treatment.

The procedures described in this study are simple to apply and are economically viable for use in clinical analysis laboratories, where equipment required to work with different glycosphingolipids is not always available, such as mass spectrometer (Groener et al., 2007; Whitfield et al., 2002) and HPLC (Ullman, McCluer, 1977). The technology tested in this study can be applied simultaneously to a considerable number of samples. Also, the method devised is advantageous compared with earlier thin-layer approaches (Vance, Sweeley, 1967) because it was standardized for a small sample volume.

The results presented in Figure 3 and Table I demonstrate an increased plasmatic GluCer level of GD patients not receiving treatment (lines 4, 5 and 7) while the plasmatic GluCer levels of normal individuals (lines 9 and 10) and patients undergoing treatment by ERT (lines 6 and 8 ) are shown to be similar. All groups demonstrated the same behavior discussed in the literature (Gornati et al., 2002; Ullman, McCluer, 1977; Vance, Sweeley, 1967).

Some authors have noted that the glucosylceramide levels in GD patients might show variations both in concentration and in distribution percentage, as a consequence of the mobility of GluCer between the plasmatic and erythrocyte lipoproteins and white blood cells (van den Bergh, Tager, 1976; G. Dawson, Oh, 1977). This fact suggests that alterations in the components of the blood such as erythrocytes and platelets can modify the plasmatic distribution pattern of glycolipids. In the present paper, plasmatic GluCer levels of GD patients without treatment were some 17 times higher than those of normal individuals.

According to Whitfeld et al. (2002), mean plasmatic GluCer levels of GD patients was $16.3 \mu \mathrm{mol} / \mathrm{L}$, while in normal individuals the value was $7.4 \mu \mathrm{mol} / \mathrm{L}$. In Groener et al. (2008), GluCer concentration in non-treated patients was observed to vary between 6.5 and $45.5 \mathrm{nmol} / \mathrm{mL}$ (mean $=17.5 \mathrm{nmol} / \mathrm{mL}$ ), while for the control group varied between 4.0 and $8.6 \mathrm{nmol} / \mathrm{mL}$ (mean $=5.9 \mathrm{nmol} / \mathrm{mL}$ ).

Our results showed a mean plasmatic GluCer level of $1.31 \mu \mathrm{mol} / \mathrm{L}$ for GD individuals without ERT versus $0.07 \mu \mathrm{mol} / \mathrm{L}$ for healthy individuals. In spite of the fact that these values are 10 times lower than those found by Whitfeld et al. (2002) and that the recovery of GluCer was about $11.2 \%$, the methodology described in this study observed a considerable difference between the groups studied. Some detection methods are known to determine lower GluCer quantities (Groener et al., 2007). Nevertheless, we emphasize that the method described in the present paper allowed the detection of differences between controls and GD patients with and without ERT treatment.

The method developed in the present study did not reveal overlapping GluCer levels between healthy individuals and GD patients ( 0 to $0.15 \mu \mathrm{mol} / \mathrm{L}$ and 0.44 to $1.76 \mu \mathrm{mol} / \mathrm{L}$, respectively). By contrast, overlapping GluCer concentration was indeed observed in a study that employed mass spectrometry to compare GluCer levels between GD patients $(0.2$ to $54.2 \mu \mathrm{mol} / \mathrm{L})$ and healthy individuals (3.7 to $14.7 \mu \mathrm{mol} / \mathrm{L})$ (Ghauharali-van der Vlugt et al., 2008).

According to Meikle et al. (2008), the lipid analysis in GD may be used to monitor the therapy and correlate it with the severity of the disease. This approach was corroborated by the findings of our study, as GD individuals on treatment showed a lower GluCer level than those not being treated. Although plasmatic chitotriosidase level is a good biomarker of GD, GD patients with deficient 
chitotriosidase activity have been reported in the literature (Guo et al., 1995). In such patients, GluCer quantification gains considerable importance. GluCer levels can be used both as an auxiliary diagnosis method for GD and as a treatment monitoring parameter.

Our experiments with primary rabbit anti-bodies for human anti-glucosylceramide indicate that the bands observed in the chromatography in fact belong to GluCer (Figure 3B). After several repetitions of extraction, purification and quantification steps with one sample, the same results were obtained, demonstrating the reproducibility of the techniques.

\section{CONCLUSIONS}

In our study, we developed a methodology to extract, purify and quantify GluCer in plasma from GD patients, and to distinguish values considered pathological from those deemed normal. Also, the technique enables measurement of the reduction in the concentration of glucosylceramide in response to ERT. Therefore, the evaluation of GluCer concentration in symptomatic and asymptomatic GD patients could be used in complementary diagnosis and as a means of monitoring the treatment. Our method appeared to be advantageous over earlier thin layer approaches used in the quantification of GluCer.

\section{ACKNOWLEDGEMENTS}

This study was supported by FAPERGS, CNPq and GPPG-HCPA.

We are grateful to Dr. Fernando Irazoqui - Centro de Investigaciones en Química Biológica de Córdoba-Republica Argentina (CIQUIBIC, UNC-CONICET).

\section{REFERENCES}

AERTS, J.M.; HOLLAK, C.; BOOT, R.; GROENER, A. Biochemistry of glycosphingolipid storage disorders: implications for therapeutic intervention. Philos. Trans. R. Soc. Lond. B. Biol. Sci., London, v.358, n.1453, p.905914, 2003.

BEUTLER, E.; GRABOWSKI, G.A. Gaucher Disease. In: SCRIVER, C.R.; BEAUDET, A. L.; SLY, W.S.; VALLE, D. (Eds.). The metabolic and molecular basis of inherited disease. 8.ed. New York: McGraw Hill, 2001. p.3635-3667.

BRADE, L.; VIELHABER, G.; HEINZ, E.; BRADE, H. In vitro characterization of anti-glucosylceramide rabbit antisera. Glycobiology, Oxford, v.10, n.6, p.629-636, 2000.
BRADY, R. O. Enzyme replacement therapy: conception, chaos and culmination. Phil. Trans. R. Soc. Lond. B. Biol. Sci., London, v.358, n.1433, p.915-919, 2003.

DAWSON, G.; OH, J.Y. Blood glucosylceramide levels in Gaucher's disease and its distribution amongst lipoprotein fractions. Clin. Chim. Acta, Amsterdam, v.75, n.1, p.149$153,1977$.

DE FOST, M.; AERTS, J.M.; HOLLAK, C.E. Gaucher disease: from fundamental research to effective therapeutic interventions. Neth. J. Med., Amsterdam, v.61, n.1, p.3-8, 2003.

DOERING, T.; HOLLERAN, W.M.; POTRATZ, A.; VIELHABER, G.; ELIAS, P.M.; SUZUKI, K.; SANDHOFF, K. Sphingolipid activator proteins (SAPs) are required for epidermal permeability barrier formation. J. Biol. Chem., Maryland, v.274, n.16, p.11038-11045, 1999.

FUTERMAN, A.H.; SUSSMAN, J.L.; HOROWITZ, M.; SILMAN, I.; ZIMRAN, A. New directions in treatment of Gaucher disease. Thends Pharmacol. Sci., Amsterdam, v.25, n.3, p.146-151, 2004.

GERMAIN, D.P. Gaucher disease: clinical, genetic and therapeutic aspects. Pathol. Biol., Paris, v.52, n.6, p.343350, 2004.

GHAUHARALI-VAN DER VLUGT, K.; LANGEVELD, M.; POPPEMA, A.; KUIPER, S.; HOLLAK, C.E.; AERTS, J.M.; GROENER, J.E. Prominent increase in plasma ganglioside GM3 is associated with clinical manifestations of type I Gaucher disease. Clin. Chim. Acta, Amsterdam, v.389, n.1-2, p.109-113, 2008.

GORNAL, A.G.; BARDAWILL, C.J.; DAVID, M.M. Determination of serum proteins by means of the biuret reaction. J. Biol. Chem., Maryland, v.177, n.2, p.751-766, 1949.

GORNATI, R.; BEMBI, B.; TONG, X.; BOSCOLO, R.; BERRA, B. Total glycolipid and glucosylceramide content in serum and urine of patients with Gaucher's Disease type 3 before and after enzyme replacement therapy. Clin. Chim. Acta., Amsterdam, v.271, n.2, p.151-161, 1998.

GORNATI, R.; BERRA, B.; MONTORFANO, G.; MARTINI, C.; CIANA, G.; FERRARI, P.; ROMANO, M.; BEMBI, B. Glycolipid analysis of different tissues and cerebrospinal fluid in type II Gaucher disease. J. Inherit. Metab. Dis., London, v.25, n.1, p.47-55, 2002. 
GROENER, J.E.; POORTHUIS, B.J.; KUIPER, S.; HOLLAK, C.E.; AERTS, J.M. Plasma glucosylceramide and ceramide in type 1 Gaucher disease patients: Correlations with disease severity and response to therapeutic intervention. Biochim. Biophys. Acta, Amsterdam, v.1781, n.1-2, p.72-78, 2008.

GROENER, J.E.; POORTHUIS, B.J.; KUIPER, S.; HELMOND, M.T.; HOLLAK, C.E.; AERTS, J.M. HPLC for simultaneous quantification of total ceramide, glucosylceramide, and ceramide trihexoside concentrations in plasma. Clin. Chem., Stanford, v.53, n.4, p.742-747, 2007.

GUO, Y.; HE, W.; BOER, A.M.; WEVERS, R.A.; DE BRUIJN, A.M.; GROENER, J.E.; HOLLAK, C.E.; AERTS, J.M.; GALJAARD, H.; VAN DIGGELEN, O.P. Elevated plasma chitotriosidase activity in various lysosomal storage disorders. J. Inher. Metab. Dis., London, v.18, n.6, p.717$722,1995$.

HAYCOCK, J.W. Polyvinylpyrrolidone as a blocking agent in immunochemical studies. Anal. Biochem., Amsterdam, v.208, n.2, p.397-399, 1993.

HOLLAK, C.E.; VAN WEELY, S.; VAN OERS, M.H.; AERTS, J.M. Marked elevation of plasma chitotriosidase activity, a novel hallmark of gaucher disease. J. Clin. Invest., Ann Harbor, v.93, n.3, p.1288-1292, 1994.

JAKÓBKIEWICZ-BANECKA, J.; WEGRZYN, A.; WEGRZYN, G. Substrate deprivation therapy: a new hope for patients suffering from neuronopathic forms of inherited lysosomal storage diseases. J. Appl. Genet., Poznan, v.48, n.4, p.383-388, 2007.

MEIKLE, P.J.; WHITFIELD, P.D.; ROZAKLIS, T.; BLACKLOCK, D.; DUPLOCK, S.; ELSTEIN, D.; ZIMRAN, A.; MENGEL, E.; CANNELL, P.; HOPWOOD, J.J.; FULLER, M. Plasma lipids are altered in Gaucher disease: biochemical markers to evaluate therapeutic intervention. Blood. Cells. Mol. Dis., Amsterdam, v.40, n.3, p.20-427, 2008.

MOYSES, C. Substrate reduction therapy: clinical evaluation in type 1 Gaucher disease. Philos. Trans. R. Soc. Lond. B. Biol. Sci., London, v.358, n.1433, p.955-60, 2003.
TANI-ICHI, S.; MARUYAMA, K.; KONDO, N.; NAGAFUKU, M.; KABAYAMA, K.; INOKUCHI, J.; SHIMADA, Y.; OHNO-IWASHITA, Y.; YAGITA, H.; KAWANO, S.; KOSUGI, A. Structure and function of lipid rafts in human activated T cells. Intern. Immunol., Oxford, v.17, n.6, p.749-758, 2005.

ULLMAN, M.D.; MCCLUER, R.H. Quantitative analysis of plasma neutral glycosphingolipids by high performance liquid chromatography of their perbenzoyl derivatives. $J$. Lipid. Res., Bethesda, v.18, n.7, p.371-378, 1977.

VAN DEN BERGH, F. A.J.T.M.; TAGER, J.M. Localization of neutral glycosphingolipids in human plasma. Biochim. Biophys. Acta, Amsterdam, v.441, n.3, p.391-402, 1976.

VANCE, D.E.; SWEELEY, C.C. Quantitative determination of the neutral glycosyl ceramides in human blood. J. Lipid. Res., Bethesda, v.8, n.6, p.621-630, 1967.

WAJNER, A.; MICHELIN, K.; BURIN, M.G.; PIRES, R.F.; PEREIRA, M.L.; GIUGLIANI, R.; COELHO, J.C. Comparison between the biochemical properties of plasma chitotriosidase from normal individuals and from patients with Gaucher disease, GM1-gangliosidosis, Krabbe disease and heterozygotes for Gaucher disease. Clin. Biochem., Amsterdam, v.40, n.5-6, p.365-369, 2007.

WHITFIELD, P.D.; NELSON, P.; SHARP, P.C.; BINDLOSS, C.A.; DEAN, C.; RAVENSCROFT, E.M.; FONG, B.A.; FIETZ, M.J.; HOPWOOD, J.J.; MEIKLE, P.J. Correlation among genotype, phenotype, and biochemical markers in Gaucher disease: implications for the prediction of disease severity. Mol. Genet. Metab., Amsterdam, v.75, n.1, p.46$55,2002$.

WILLIAMS, M.A.; MCCLUER, R.H. The use of Sep-Pak C18 cartridges during the isolation of gangliosides. $J$. Neurochem., Boston, v.35, n.1, p.266-269, 1980.

ZIMRAN, A.; ELSTEIN, D. Gaucher disease and the clinical experience with substrate reduction therapy. Philos. Trans. R. Soc. Lond. B. Biol. Sci., London, v.29, n.1433, p.961966, 2003.

Received for publication on 10 February 2010. Accepted for publication on 10 May 2010. 